\title{
Comparison of the nutritional status in children aged 5 to 10 years old on the Conditional Cash Transfer Programme in the States of Acre and Rio Grande do Sul, Brazil
}

Anderson Gonçalves Freitas ${ }^{1}$, Diego Gonçalves de Lima1, Miguel Junior Sordi Bortolini ${ }^{2}$, Dionatas Ulises de Oliveira Meneguetti ${ }^{3}$, Edigê Felipe de Sousa Santos ${ }^{4}$ Hugo Macedo Junior ${ }^{5}$, Romeu Paulo Martins Silva ${ }^{6}$

DOI:http://dx.doi.org/10.7322/jhgd.121206

\begin{abstract}
Introduction: In recent years, there has been a reduction in cases of malnutrition in Brazil but this has been accompanied with an increase in the overweight and obesity rates. These changes, together with others, such as changes in eating patterns and lifestyle, characterise the process of nutritional transition.

Objective: We aimed to compare the prevalence of nutritional status of beneficiary children of the Bolsa Familia Program (PBF) in the states of Acre and Rio Grande do Sul, Brazil, and to analyse the changes in the anthropometric profile of these children during 5 years.

Methods: This is an ecological study using secondary data from the Food and Nutrition Surveillance System (SISVAN) and Bolsa Família Department of SUS (DATASUS), which assessed the nutritional status of children over 5 years and under 10 years benefiting from the PBF in the years 2011 to 2015 in the states of Acre and Rio Grande do Sul. The sample consisted of 94,865 children from Acre and 342,462 children from Rio Grande do Sul. The Body Mass Index was used to classify the nutritional status.

Results: The mean prevalence of eutrophic children aged 5 to 10 years in Acre was $70.42 \%$ and was $61.28 \%$ in Rio Grande do Sul. Overweight was $13.06 \%$ in Acre and $19.48 \%$ in Rio Grande do Sul. Obesity was $5.08 \%$ in Acre and $9.36 \%$ in Rio Grande do Sul. Severe obesity was $4.02 \%$ in Acre and $6.92 \%$ in Rio Grande do Sul.

Conclusion: Overweight and obesity in children benefiting from the PBF has been growing in the last 5 years, notably in the state of Rio Grande do Sul. This is possibly due to the fact that the nutritional transition is at a more advanced stage here than in Acre State.
\end{abstract}

Keywords: nutritional status, prevalence, child, public policy.

\section{INTRODUCTION}

Brazil, like other developing countries, has passed the nutritional transition including changes in traditional dietary pattern, replacing fibre and complex carbohydrates with the high intake of fat and red meat ${ }^{1}$. The nutritional transition can be characterised by four stages: progressive disappearance of "Kwashiorkor" or oedematous malnutrition; disappearance of nutritional marasmus; appearance of binomial overweight/obesity; and finally, deficit height $^{2}$.

The constant increase in overweight and obesity in the world has already been seen as an epidemic and it has affected all social classes and all ages. The numbers of

1 Nutricionista, Mestrando em Ciências da Saúde na Amazônia Ocidental da Universidade Federal do Acre - UFAC - Bloco Francisco Mangabeira Sala 17 - Campus Universitário - $1^{\circ}$ Piso, BR 364, Km 04 - Distrito Industrial, CEP 69915-900 - Rio Branco-AC.

2 Doutor em Imunologia e Parasitologia Aplicadas, Prof. Dr. ${ }^{\circ}$ Universidade Federal do Acre - UFAC - Bloco Francisco Mangabeira Sala 17 - Campus Universitário - $1^{\circ}$ Piso, BR 364, Km 04 - Distrito Industrial, CEP 69915-900 - Rio Branco-AC.

3 Doutor em Biologia Experimental, Prof. Dr. ${ }^{\circ}$ Universidade Federal do Acre - UFAC. - Bloco Francisco Mangabeira Sala 17 - Campus Universitário - $1^{\circ}$ Piso, BR 364, Km 04 - Distrito Industrial, CEP 69915-900 - Rio Branco-AC

4 Mestre em Ciências da Saúde. Departamento de Epidemiologia, Faculdade de Saúde Pública da Universidade de São Paulo, São Paulo, São Paulo, Brasil.

5 Médico Sanitarista, Doutor em Saúde Pública. Professor do departamento de saúde da coletividade da Faculdade de Medicina do ABC, Santo André , SP, Brasil.

6 Doutor em Genética e Bioquímica, Prof. Dr. ${ }^{\circ}$ Universidade Federal do Acre - UFAC.- Bloco Francisco Mangabeira Sala 17 - Campus Universitário - $1^{\circ}$ Piso, BR 364, Km 04 - Distrito Industrial, CEP 69915-900 - Rio Branco-AC.

Pesquisa realizada no Centro de Ciências da Saúde e do Desporto da Universidade Federal do Acre.

Correspondig author: - Email: anderson.freitas2@hotmail.com

Suggested citation: Freitas AG, Lima DG, Bortolini MJS, Meneguetti DUO, Santos EFS, Silva RPM. Comparison of the nutritional status in children aged 5 to 10 years old on the Conditional Cash Transfer Programme in the States of Acre and Rio Grande do Sul, Brazil. J Hum Growth Dev. 2017; 27(1) 35-41: DOI: http://dx.doi.org/10.7322/jhgd.121206

Manuscript submitted in 2016, accepted for publication in Jan 2017. 
overweight children in the United States tripled between 1980 and $2000^{3}$. As several studies demonstrate, Brazil has followed a similar pattern. For example, Abrantes, Lamounier and Colosimo ${ }^{4}$, assessed overweight and obesity in children and adolescents from the northeast and southeast regions of Brazil and found a prevalence of obesity in $8.2 \%$ and $11.9 \%$, respectively. Balaban and Silva ${ }^{5}$ observed that in children and adolescents at a school in Recife, overweight and obesity were statistically more significant in children, reaching a prevalence of $26.2 \%$ and $8.5 \%$ of the sample, respectively.

In Brazil, the conditional cash transfer program, which is known as the Bolsa Família Program (PBF), was established by Law no. 10,836 on 9 January 2004 and was regulated by Decree no. 5209 on 18 November 2004. The PBF was created to improve the quality of a poor extract of the population through direct income transfer, subject to certain obligations that are designed to give this population access to public services ${ }^{6}$. The programme holders are mostly individuals at risk, the majority of whom are black or brown (64\%), with primary school education $(56 \%)$, with most of the holders being women (94\%) and single mothers $(27 \%)^{7}$.

The Food and Nutrition Surveillance Information System (SISVAN) is a health information system that transforms data into information and whose objective is to evaluate nutritional status through anthropometric measures of the individuals and, thus, provide a diagnosis of the nutritional situation. This allows us to allocate public policies for the most vulnerable population ${ }^{8}$.

The objective of this study is to compare the prevalence of the nutritional profile of beneficiary children of the PBF of two Brazilian states, the State of Acre (AC) and Rio Grande do Sul (RS), as well as to analyse changes in the anthropometric profile of these children for a period of 5 years.

\section{METHODS}

This is an ecological study carried out from secondary data, where the nutritional status of children over 5 years of age and under 10 years of age on the PBF was evaluated during the period 2011 to 2015 in the states of $\mathrm{AC}$ and RS. The data were obtained through the Food and Nutrition Surveillance System (SISVAN) and Bolsa Família, available at the Department of Information Technology of the SUS (DATASUS) website (www.datasus. gov.br). The method used in this study followed similarly to study of Silva and Nunes ${ }^{9}$, which analysed the same age group but in the state of Mato Grosso do Sul in 2010.

The state of AC has $164.123 \mathrm{~km}$ of territory, it is located in the north of Brazil and is composed of 22 municipalities with an estimated population in 2015 of 803,513 inhabitants ${ }^{10}$. AC has a the Human Development Index (HDI) of 0.663 , being the penultimate of the region, just ahead of Pará State ${ }^{11}$.

RS has 281,737 km territory, it is located in the south of Brazil and is composed of 497 municipalities with an estimated population in 2015 of $11,247,972$ inhabitants ${ }^{12}$. This state has the worst HDI of 0.746 region $^{11}$.
The choice of the HDI was made because it is a composite index that combines three of the most important dimensions of human development, which are: the opportunity to live a long and healthy life, having access to knowledge, and having a standard of living that ensures the basic needs, as represented by health, education and income ${ }^{13}$.

For the present study, information was collected on 5 to 10 year old children from $\mathrm{AC}$ and $\mathrm{RS}$ who were beneficiaries of the PBF in the years 2011 to 2015, and described the process in figure 1. In 2011, there were 10,401 children aged 5 to 10 years in $\mathrm{AC}$ and 54,018 in RS for the nutritional status of both genders. In 2012, in AC there were 11,249 and in there were RS 53,347. In the year of 2013, there were part records of 19,004 in AC and 71,798 in RS. In 2014, in AC there were 26,371 and in RS there were 81,930 .Finally, in $2015,27,840$ children were enrolled in AC and 81,369 were enrolled in RS.

Figure 1. Flow of selection of the data collected through the SISVAN WEB

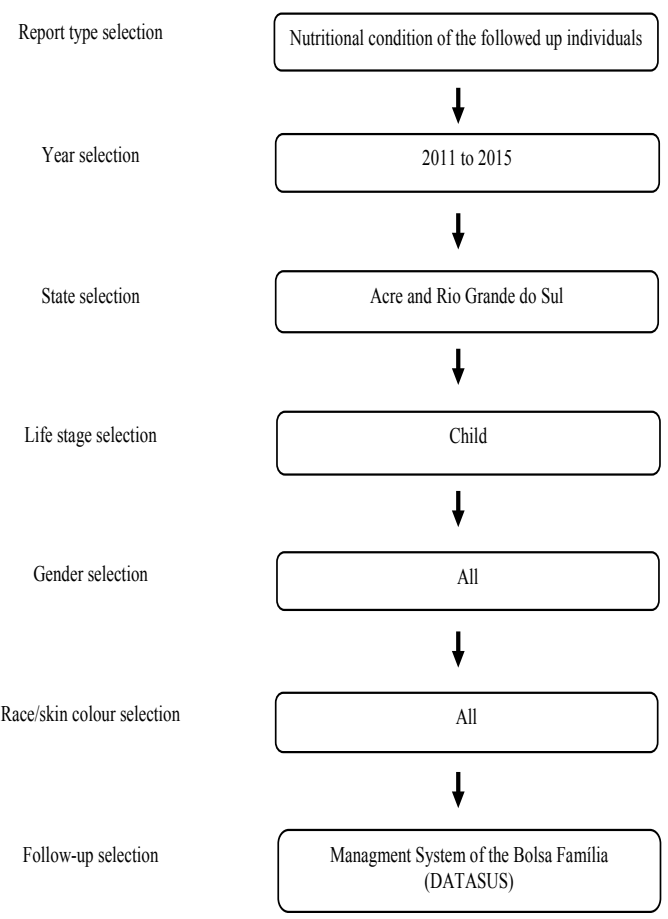

The body mass index (BMI), which was calculated by dividing the body mass $(\mathrm{kg})$ by the square of height (m), was used to classify the nutritional status of the PBF beneficiary children. The World Health Organisation cutoffs ${ }^{14}$ were used as a reference, as employed by SISVAN from 2008. The BMI cut-offs vary according to age and nutritional status and can be classified from percentile and/or Z-score. The Z-score was used in this research and was calculated by SISVAN itself. The following six cutoffs for BMI are defined based on the Z-score ${ }^{14}$ : a) sharp thinness $(<-3)$; b) thinness $(>-3$ and $<-2)$; c) eutrophic $(>-2$ and $<+1)$; d) overweight $(>+1$ and $<+2)$; e) obesity $(>+2$ and $<+3)$; and $\mathrm{f})$ severe obesity $(>+3)$. For this study, the categories described in items a and $b$ will not be used; only items c, d, and e are used.

Anthropometric measurements were collected and recorded as the standardisations of SISVAN ${ }^{15}$. The body mass measurement is obtained with a calibrated scale, 
which can be a mechanical platform or digital. Stature is assessed with a vertical anthropometry or by using an anthropometric tape affixed to the wall. The health primary care professionals who are responsible for data collection received the manual and followed the procedures contained in the document ${ }^{15}$.

For the treatment of the data, Excel was used to obtain information from the SISVAN website and to analyse the information in a descriptive way (absolute and relative frequencies). We used GraphPad Prism ${ }^{\circledR}$ version 5.00 for the calculation of differences between the proportions. A significance level of 5\% was adopted.

The present study involves only the description and analysis of secondary data. All of these sources of information are in the public domain. In particular, no information with individual identification was obtained for this study. Thus, this study waived the opinion of an ethics committee.

\section{RESULTS}

Table 1 shows the prevalence of 5-year nutritional status of PBF recipients in the states of $\mathrm{AC}$ and $\mathrm{RS}$. It is observed that there is an increase in the prevalence of eutrophic nutritional status during the 5 years in children from AC when compared to RS. The prevalence of overweight and obesity were higher in RS. Severe obesity in the children of AC has decreased over the years analysed. A significant association was found between the two states and in all of the items used in the present study (Table 1).

As can be seen in Figure 2, in the period from 2011

Table 1: Prevalence (\%) of eutrophic, overweight, obesity and severe obesity in Acre and Rio Grande do Sul in beneficiaries children aged five to ten of the Programa Bolsa Família, 2011 - 2015.

\begin{tabular}{|c|c|c|c|c|c|c|c|c|}
\hline \multirow[t]{3}{*}{ Years } & \multicolumn{8}{|c|}{ Nutritional Status } \\
\hline & \multicolumn{2}{|c|}{ Eutrophic } & \multicolumn{2}{|c|}{ Overweight } & \multicolumn{2}{|c|}{ Obesity } & \multicolumn{2}{|c|}{ Severe Obesity } \\
\hline & $A C$ & RS & $A C$ & RS & $A C$ & RS & $A C$ & RS \\
\hline 2011 & 69,5 & 62,8 & 12,0 & 19,0 & 4,8 & 8,3 & 4,9 & 6,7 \\
\hline 2012 & 69,5 & 61,9 & 13,0 & 19,1 & 5,1 & 8,9 & 4,5 & 7,0 \\
\hline 2013 & 70,4 & 60,9 & 13,3 & 19,6 & 5,0 & 9,5 & 4,1 & 7,1 \\
\hline 2014 & 70,8 & 60,6 & 13,3 & 19,7 & 5,1 & 9,9 & 3,6 & 7,0 \\
\hline \multirow[t]{2}{*}{2015} & 71,9 & 60,2 & 13,7 & 20,00 & 5,4 & 10,2 & 3,0 & 6,8 \\
\hline & \multicolumn{2}{|c|}{$P<0,001$} & \multicolumn{2}{|c|}{$P<0,001$} & \multicolumn{2}{|c|}{$P<0,001$} & \multicolumn{2}{|c|}{$P<0,001$} \\
\hline
\end{tabular}

Abbreviations: AC: Acre; RS: Rio Grande do Sul.

to 2015, the average prevalence of eutrophic beneficiary children in the age group 5 to 10 years in $\mathrm{AC}$ was $70.42 \%$ and was $61.28 \%$ in RS. The overweight group was $13.06 \%$ in $\mathrm{AC}$ and $19.48 \%$ in RS. Obesity was $5.08 \%$ in AC and $9.36 \%$ in RS. Severe obesity was $4.02 \%$ in the AC and
$6.92 \%$ in RS. A difference was observed between the two states in all of the variables analysed, with statistical significance $(p<0.001)$. RS accumulate higher levels of overweight, obesity and severe obesity when compared to AC.

Figure 2: Comparison of the five-year prevalence of nutritional conditions of Acre e do Rio Grande do Sul

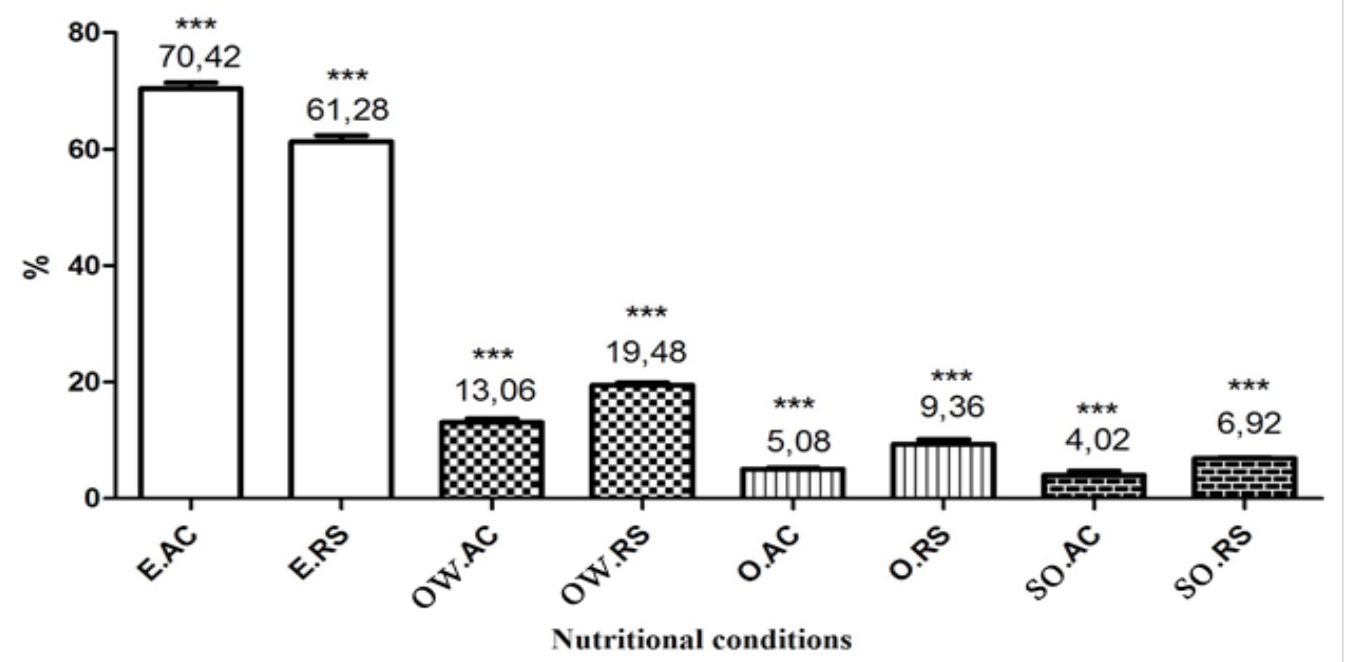

AC - Acre; RS - Rio Grande do Sul; E - Eutrophic; OW - Overweight; O - Obesity; SO - Severe Obesity. $* * *-p<0,001$. 


\section{DISCUSSION}

The results showed the nutritional profile of the children benefiting from the PBF. The prevalence of overweight (overweight+obesity) increased in AC and RS during the analysed years. In addition, in the RS state the prevalence of eutrophy reduced while in AC the opposite was observed. In addition, the children from RS had higher values of obesity and severe obesity.

In relation to anthropometric data, the prevalence of eutrophic was $70.4 \%$ in $\mathrm{AC}$ and $61.3 \%$ in $\mathrm{RS}$, while the prevalence of overweight was $13 \%$ in $\mathrm{AC}$ and $19 \%$ in RS. This result is similar to that found by Pelegrini et al. ${ }^{15}$, who evaluated 2,913 children from seven to nine years old living in Brazil and estimated that the prevalence of normal weight of $81.9 \%$ and $72.3 \%$, respectively, in the north and south and overweight of $13 \%$ and $17.5 \%$. When comparing three references to classify nutritional status, Melo et al. ${ }^{16}$ obtained a prevalence of $77.4 \%$ of normal weight and $13.1 \%$ overweight in Rio Branco children, AC. Overweight data were also similar to those found in two north-eastern capitals (Recife was $12.9 \%$ and Sergipe was $13.2 \%)^{9,17}$. On the other hand, there was a lack of available data on the nutritional status of children in the Amazon region.

It was also verified that overweight children showed a growing tendency during the years studied in both states. Even with different socioeconomic and cultural characteristics, the prevalence continues to increase. With the digital revolution, urbanisation and violence in large cities, the standard of life of children and adolescents has also changed over the years, increasing the time spent in front of TVs or computers ${ }^{18}$, helping to lift overweight indicators and obesity.

A study conducted with PBF beneficiary families in Curitiba, Paraná, notified the individuals who reported their food as inadequate, which could be caused by several reasons, such as lack or low consumption of vegetables and fruits, or because of the high costs of these products ${ }^{19}$. When poor families have higher incomes they tend to spend more on foods that are rich in sugars and fats, and this may be the reason for the increase of overweight observed in this layer ${ }^{20}$. Socioeconomic status interferes in the prevalence of overweight and obesity in that it determines the availability of food and access to information ${ }^{17}$.

Obesity is a disease of multifactorial origin and its prevalence among children has increased worldwide. The main risks to the health of obese children are hyperlipidaemia, systemic hypertension, and psychological source of damage because obese children are discriminated against ${ }^{21}$. A prevalence of $5.08 \%$ of obesity in children from $\mathrm{AC}$ and $9.36 \%$ in children from RS was found. These findings are similar to the results of Rech et al. ${ }^{22}$, who researched schoolchildren aged 7 to 12 years on a mountain city of RS and found obesity rates of $7.4 \%, 8.4 \%, 7.2 \%$ and $9.8 \%$ for children 7, 8, 9 and 10 years, respectively. Oliveira et $\mathrm{al}^{23}$ found that there was a positive association between high levels of parental education, high family income, and presence of home appliances such as TV, computer and video game with obesity. This fact may explain the difference between the prevalence of the disease in these states because the population of RS has greater purchasing power and more access to consumer goods.

Regarding the increase of overweight in children and adolescents in urban, rural and indigenous areas, changes in lifestyle have favoured the prevalence excess weight of $14 \%$ to $30 \%{ }^{24}$. Thus, it has been shown that poor eating habits and sedentary lifestyle are not just characteristics of urban centres. These data corroborate with those found in this study, which shows that obesity and overweight in PBF beneficiary children has grown in more urban areas, such as in the south, and in more rural areas, such as in the north.

Mantovani et al. ${ }^{25}$ evaluated the height for age in children aged under 5 years old in one AC municipality and found that stunting is still present with a prevalence of $14.4 \%$ of the sample. Low stature for age may indicate accumulated malnutrition over a long period, adversely affecting health and often without possibility of recovery, impeding the full physical development of children. The maternal economic situation and open sewage were variables that showed an increase in short stature in the sample according to the authors. Their study corroborates the idea that the AC population lives in the extremes of malnutrition and obesity.

Accurate classification of the nutritional profile of children is crucial in determining the extent of problems at the public health level. In the diagnosis of overweight and obesity by BMI in children and adolescents, there are several national and international anthropometric recommended references that hinder the development of overweight and obesity prevention actions ${ }^{16}$. It is also worth noting that our data are maintained by the Ministry of Health and, therefore, are reliable and representative of the population. This makes it a feasible tool to establish more accurate data on the nutritional profile of beneficiary children of the PBF of the states of AC and RS.

Researchers have analysed data from 17,561 children from Europe Asia and Africa, and found that a sedentary lifestyle, family risk behaviour (maternal obesity, smoking near the child and not eat breakfast), low income and low education were the factors more associated with childhood obesity ${ }^{26}$. In Brazil, Abrantes, Lamounier and Colosimo 4 evaluated obesity in children of the northeast and southeast and found that obesity was increasingly prevalent in the southeast ( $8.2 \%$ and $11.9 \%$, respectively). This result is similar to that found in this present study, in which AC is in a more favourable situation than RS. One can attribute this fact to the food characteristics of the population of different localities. The parents' habits directly influence the food preference and physical activity habits of their children ${ }^{27-29}$. The state of AC is still considered to be underdeveloped and it has no access to shopping centres, it is not bombarded by marketing of fast-food outlets and it still retains the traditional food culture.

Silva estimated the prevalence of overweight and obesity in children living in a capital city in the northeast and beneficiaries of income transfer program and identified prevalence of obesity between $11 \%$ and $15.1 \%$, recommending priority of health services for this population $^{30}$. Saldanha et al. ${ }^{31}$ found similar results in children of a capital in the southeast, concluding that the population 
covered by the Family Grant Programme is going through the process of nutritional transition. This change in food pattern reflects the increase in overall food consumption, including processed foods of high caloric density and low nutritional quality.

According to work proposed by Bezerra and Sorpreso $^{32}$, it is important that health promotion practices trigger mechanisms that are aimed at the creation or re-creation of a new model to produce health, in order to overcome the actions still oriented by the exclusively biological approach. The monitoring was carried out by professionals from the primary level to the $\mathrm{PBF}$, which is a great incentive for the eradication of weakness and poverty, including educational and training activities to children and their families ${ }^{33}$.Therefore, PBF-assisted population characterisation studies may be able to induce improvements in the quality of children health care, including at the primary level, where prevention and treatment measures remain ineffective.

Machado et al. ${ }^{34}$ showed that the school health programme in Brazil has mobilised relevant actions with health care professionals in schools, even if it has not been used homogeneously in all Brazilian regions. The regions that have the most accomplished actions are in the north and northeast. This may be a possible explanation why the nutritional status of the children in AC is better than that of children in RS. This may be associated to the fact that these regions have greater social and economic inequalities, and have had a longer history of the use of health teams.

Searches using secondary data have several limitations and they can be subject to errors of registration, typing and under-reporting, which is a limitation of this study. It was not possible to identify new registrations of children in PBF from year to year, only the total existing beneficiaries of the programme was available.

Although the results obtained in this study bring data from two Brazilian states with different characteristics, they had both experienced increases in the prevalence of overweight and obese children. In terms of public health, indicators of morbidity and its direct association with assisted age groups guide high quality services. Population characterisation studies are important for tracking, planning, and effectively allocating health resources to populations at risk, and may be able to induce improvements in the quality of health care of these children, including the primary level, in which excess prevention measures remain ineffective.

Individuals benefiting from the PBF showed an increase in the overweight and obesity strata. This demonstrates that the nutritional profile of these children is not adequate and it can be justified that this population has access to food in general, including processed foods and the globalisation of unhealthy habits.

It can be concluded that the numbers of overweight and obese children receiving PBF have increased in the last 5 years, notably in the state of RS. This possibly happened because the nutritional transition is already at a more advanced stage in RS than in the state of AC.

\section{Interest conflicts}

The authors of this manuscript declare there are no conflicts of interest involved.

\section{REFERENCES}

1. Popkin BM. The nutrition transition and its health implications in lower-income countries. Public Health Nutr. 1998;1(1):5-21. DOI: https://doi.org/10.1079/PHN19980004

2. Batista Filho M, Rissin A. A transição nutricional no Brasil: tendências regionais e temporais. Cad Saude Publica. 2003;19(Sup. 1):S181-91. DOI: http://dx.doi.org/10.1590/S0102-311X2003000700019

3. Ogden CL, Kuczmarski RJ, Flegal KM, Mei Z, Guo S, Wei R, et al. Centers for Disease Control and Prevention 2000 Growth Charts for the United States: Improvements to the National Centre for Health statistics Version. Pediatrics. 2002;109(1):45-60. DOI: http://dx.doi.org/10.1542/peds.109.1.45

4. Abrantes MM, Lamounier JA, Colosimo EA. Prevalência de sobrepeso e obesidade em crianças e adolescentes das regiões Sudeste e Nordeste from Northeast and Southeast regions of Brazil. J Pediatr (Rio J) 2002;78(4):335-40. DOI: http://dx.doi.org/10.1590/S0021-75572002000400014

5. Balaban G, Silva G a. P Da. Prevalência de sobrepeso e obesidade em crianças e adolescentes de uma escola da rede privada de Recife. J Pediatr (Rio J). 2001;77:96-100. DOI: http://dx.doi.org/10.1590/ S0021-75572001000200008

6. Brasil. Ministério da Saúde. Ministério do Desenvolvimento e Combate à fome. Manual de orientações sobre o Bolsa Família na saúde. $3^{\mathrm{a}}$ ed. Brasília: SUS; 2010.

7. Instituto Brasileiro de Análises Sociais e Econômicas (IBASE). Repercussões do Programa Bolsa Família na segurança alimentar e nutricional das famílias beneficiadas. Rio de Janeiro: Ibase; 2008.

8. Vigilância Alimentar e Nutricional (SISVAN). Orientações básicas para a coleta, processamento, análise de dados e informação em serviços de saúde. Brasília: Ministério da Saúde; 2004.

9. Silva DAS, Nunes HEG. Prevalence of underweight, overweight and obesity in poor children from Mato Grosso do Sul. Rev Bras Epidemiol. 2015;18(2):466-75. DOI: http://dx.doi.org/10.1590/19805497201500020014

10. Instituto Brasileiro de Geografia e Estatística (IBGE). Estados: Acre. [cited 2016 Jul 17] Available from: http://www.ibge.gov.br/estadosat/perfil.php?lang=\&sigla=ac.

11. Programa das Nações Unidas para o Desenvolvimento (PNUD). Ranking IDHM Unidades da Federação 2010. [cited 2016 Jul 17] Available from: http://www.pnud.org.br/atlas/ranking/Ranking-IDHM-UF-2010.aspx 
12. Instituto Brasileiro de Geografia e Estatística (IBGE). Estados: Rio Grande do Sul. [cited 2016 Jul 17] Available from: http://www.ibge.gov.br/estadosat/perfil.php?sigla=rs

13. Programa das Nações Unidas para o Desenvolvimento (PNUD). O que é IDH. [cited 2016 Jul 17] Available from: http://www.br.undp.org/content/brazil/pt/home/idh0/conceitos/o-que-e-o-idh.html

14. World Health Organization (WHO). WHO Child Growth Standards: length/height-for-age, weight-for-age, weight-for-length, weight-for-height and body mass index-for-age: methods and development. Geneva: WHO; 2006.

15. Pelegrini A, Silva DAS, Petroski EL, Gaya AC. Overweight and obesity in seven to nine-year-old Brazilian students: data from the Brazilian Sports Project. Rev Paul Pediatr. 2010;28(3):290-5. DOI: http://dx.doi.org/10.1590/S0103-05822010000300006

16. Melo ME, Miguéis GL, Almeida MS, Dalamaria T, Souza OF. Overweight and obesity of children in a brazilian elementary school: a comparison of three references. J Hum Growth Dev. 2016;26(3):341-344. DOI: http://dx.doi.org/10.7322/jhgd.122817

17. Silva GAP, Balaban G, Motta MEFA. Prevalência de sobrepeso e obesidade em crianças e adolescentes de diferentes condições socioeconômicas. Rev Bras Saúde Matern Infant. 2005;5(1):53-9. DOI: http://dx.doi.org/10.1590/S1519-38292005000100007

18. Rinaldi AEM, Pereira AF, Macedo CS, Mota JF, Burini RC. Contribuições das práticas alimentares e inatividade física para o excesso de peso infantil. Rev Paul Pediatr. 2008;26(3):271-7. DOI: http://dx.doi.org/10.1590/S0103-05822008000300012

19. Uchimura KY, Bosi MLM, Lima FEL, Dobrykopf VF. Qualidade da alimentação: percepções de participantes do programa bolsa família. Cienc Saude Coletiva. 2012;17(3):687-94. DOI: http://dx.doi.org/10.1590/ S1413-81232012000300015

20. Saldiva SRDM, Silva LFF, Saldiva PHN. Avaliação antropométrica e consumo alimentar em crianças menores de cinco anos residentes em um município da região do semiárido nordestino com cobertura parcial do programa bolsa família. Rev Nutr. 2010;23(2):221-9. DOI: ttp://dx.doi.org/10.1590/S1415-52732010000200005

21. Soares LD, Petroski EL. Prevalência, fatores etiológicos e tratamento da obesidade infantil. Rev Bras Cineantropom Desempenho Hum. 2003;5(1):63-74.

22. Rech RR, Halpern R, Costanzi CB, Bergmann MLA, Alli LR, Mattos AP, et al. Prevalência de obesidade em escolares de 7 a 12 anos de uma cidade Serrana do RS, Brasil. Rev Bras Cineantropom Desempenho Hum. 2010;12(2):90-7. DOI: http://dx.doi.org/10.5007/1980-0037.2010v12n2p90

23. Oliveira AMA, Cerqueira EMM, Souza JS, Oliveira AC. Sobrepeso e Obesidade Infantil: Influência de Fatores Biológicos e Ambientais em Feira de Santana, BA. Arq Bras Endocrinol Metab. 2003;47(2):144-50. DOI: http://dx.doi.org/10.1590/S0004-27302003000200006

24. Tagliari IA, Rocha Ferreira MB, Silva LR, Pizzi J, Leite N. Overweight and low height in children of urban, rural and indigenous communities. J Hum Growth Dev. 26(1):67-73. DOI: http://dx.doi.org/10.7322/jhgd.105

25. Mantovani SAS, Ramalho AA, Pereira TM, Branco FLCC, Oliart-Guzmán H, Delfino BM, et al. Stunting in children under five years old is still a health problem in the Western Brazilian Amazon: a populationbased study in Assis Brasil, Acre, Brazil. Ciênc Saúde Coletiva. 2016;21(7):2257-66. DOI: http://dx.doi. org/10.1590/1413-81232015217.18602014

26. Brophy S, Cooksey R, Gravenor MB, Mistry R, Thomas N, Lyons RA, et al. Risk factors for childhood obesity at age 5: analysis of the millennium cohort study. BMC Public Health 2009;9:467. DOI: http://dx.doi. org/10.1186/1471-2458-9-467

27. Sena RA, Prado SRLA. Obesidade infantil relacionada a hábitos de vida e práticas alimentares. Rev Enferm UNISA. 2012;13(1):69-73.

28. Rossi A, Moreira EAM, Rauen MS. Determinantes do comportamento alimentar: Uma revisão com enfoque na família. Rev Nutr. 2008;21(6):739-48. DOI: http://dx.doi.org/10.1590/S1415-52732008000600012

29. Ramos M, Stein LM. Development of children's eating behavior. J Pediatr (Rio J). 2000;76(Supl. 3):229-37. DOI: http://dx.doi.org/10.2223/JPED.160

30. Silva DAS. Sobrepeso e obesidade em criancas de cinco a dez anos de idade beneficiarias do programa bolsa familia no estado de Sergipe, Brasil. Rev Paul Pediatr. 2011;29(4):529-35. DOI: http://dx.doi. org/10.1590/S0103-05822011000400010

31. Saldanha LF, Lagares ÉB, Fonseca PC, Anastácio LR. Nutritional status of children who are recipients of the Family Allowance Program followed up by the Food and Nutrition Surveillance System in the State of Minas Gerais. Rev Médica Minas Gerais. 2014;24(4):478-85. DOI: http://www.dx.doi.org/10.5935/22383182.20140139

32. Bezerra IMP, Sorpreso ICE. Concepts and movements in health promotion to guide educational practices. J Hum Growth Dev. 26(1): 11-20. DOI: http://dx.doi.org/10.7322/jhgd.113709 
33. Santos FPC, Vitta FCF, Conti MHS, Mata SN, Gatti MAN, Simeão SFAP, et al. Nutritional condition of children who benefit from the "Bolsa Família" programme in a city of northwestern, São Paulo state, Brazil. J Hum Growth Dev. 25(3):313-18. DOI: http://dx.doi.org/10.7322/jhgd.106003

34. Machado MFAS, Gubert FA, Meyer APGFV, Sampaio YPCC, Dias MSA, Almeida AMB, et al. The health school programme: a health promotion strategy in primary care in Brazil. J Hum Growth Dev. 25(3):307-12. DOI: http://dx.doi.org/10.7322/jhgd.96709

This article is distributed under the terms of the Creative Commons Attribution 4.0 International License (http://creativecommons.org/licenses/by/4.0/), which permits unrestricted use, distribution, and reproduction in any medium, provided you give appropriate credit to the original author(s) and the source, provide a link to the Creative Commons license, and indicate if changes were made. The Creative Commons Public Domain Dedication waiver (http://creativecommons.org/publicdomain/zero/1.0/) applies to the data made available in this article, unless otherwise stated.

\section{Resumo:}

Introdução: No Brasil tem-se observado que houve uma redução nos casos de desnutrição nos últimos anos, porém acompanhado a esse decréscimo houve um aumento em relação às taxas de sobrepeso e obesidade. Essas mudanças em conjunto com outras como alteração dos padrões alimentares e o estilo de vida caracterizam o processo de transição nutricional.

Objetivo: Comparar as prevalências do perfil nutricional de crianças beneficiárias do Programa Bolsa Família dos estados do Acre e do Rio Grande do Sul, assim como analisar mudanças no perfil antropométrico dessas crianças por período de cinco anos.

Método: Trata-se de estudo ecológico utilizando dados secundários do Sistema de Vigilância Alimentar e Nutricional (SISVAN) e Bolsa Família do Departamento de Informática do SUS (DATASUS), no qual foi avaliado o estado nutricional de crianças maiores de cinco anos e menores de dez anos beneficiárias do Programa Bolsa Família (PBF) no ano de 2011 a 2015 nos estados do Acre e Rio Grande do Sul. A amostra constituiu de 94.865 crianças do Acre e 342.462 crianças do Rio Grande do Sul. Para classificar o estado nutricional utilizou-se o Índice de Massa Corporal/idade.

Resultados: A média da prevalência de eutrofia de crianças na faixa etária cinco a dez anos beneficiárias no Acre foi de $70,42 \%$ e $61,28 \%$ no Rio Grande do Sul; o sobrepeso foi de $13,06 \%$ no Acre e $19,48 \%$ no Rio Grande do Sul; a obesidade 5,08\% no Acre e 9,36\% no Rio Grande do Sul; e a obesidade grave $4,02 \%$ no Acre e $6,92 \%$ no Rio Grande do Sul.

Conclusão: O sobrepeso e obesidade em crianças beneficiárias do PBF tem crescido nos últimos cinco anos, notadamente no estado do Rio Grande do Sul possivelmente pelo fato da transição nutricional já estar em um estágio mais avançado do que no Estado Acre.

Palavras-chave: estado nutricional, prevalência, criança, políticas públicas. 